\title{
Women's Voices, Work and Bodily Integrity in Pre-Conflict, Conflict and Post-Conflict Reconstruction Processes in Sierra Leone
}

\author{
Hussainatu J. Abdullah, Aisha F. Ibrahim and Jamesina King
}

\begin{abstract}
This article focuses on the historical trajectories of women's empowerment in Sierra Leone, taking three entry-points as a means of exploring the dynamics of change over the pre-conflict, conflict and postconflict periods: voice and political participation; work and economic participation; and bodily integrity. Looking at pathways of empowerment in pre-conflict Sierra Leone, at experiences of women during the time of conflict over the course of a long and brutal civil war from 1991-2002, and at post-conflict possibilities, the article highlights some of the changes that have taken place in women's lives and the avenues that are opening up in Sierra Leone in a time of peace. It suggests that understanding women's pathways of empowerment in Sierra Leone calls for closer attention to be paid to the dynamics of conflict and post-conflict reconstruction, and to the significance of context in shaping constraints and opportunities.
\end{abstract}

\section{Introduction}

'In the very break down of morals, traditions, customs and community, war also opens up and creates new beginnings.' (Turshen 1998: 20)

This article reflects on changes in Sierra Leonean women's lives before, during and in the aftermath of a brutal and protracted civil war endured over the years 1991-2002. The onset of the civil war and its devastating effects on the economy and society brought about dramatic changes in Sierra Leonean women's everyday lives. Yet it also opened up spaces for women's voices. The expansion of educational opportunities gave rise to a crop of highly articulate and educated women, willing to challenge the state and demand a restructuring of gender relations to ensure equality. Women's independent organising became a new pathway of women's empowerment in wartime Sierra Leone, and has opened new avenues for women to articulate their demands for equal rights and social justice in a postwar situation. Sierra Leonean women started demanding legal reforms to promote and protect their rights, equal and fair representation in politics, and access to economic resources to strengthen their financial positions in society, among others.

This article explores trajectories of change in Sierra Leone through three entry-points - voice and political participation, work and economic participation, and bodily integrity - and focuses not only on the challenges brought on by the war, but also the opportunities created by it. It examines how women have or have not used these openings to transform their existence and status in society. In doing so, we suggest that understanding women's pathways of empowerment in Sierra Leone calls for closer attention to be paid to the dynamics of conflict and post-conflict reconstruction, and to the significance of context in shaping constraints and opportunities.

\section{Voice: women, politics and empowerment 2.1 Women emerging as leaders in the pre-conflict era In a part of the world marked by the low numbers of women in political office, Sierra Leonean women have a distinguished history of participation in politics, as chiefs, paramount chiefs, mayors, cabinet ministers and members}


of parliament. Sierra Leonean women's participation in politics has, however, been based on individual recognition (such as educational qualification and/or political party affiliation) rather than women's independent organising using their organisational base as a platform for political engagement. As a result, access to political office has been based on tokenism and the benevolence of male leaders.

The dominance of personal achievement as the route to female participation in politics does not mean that women have not tried to use their organisations as a platform for political activism. Mrs Constance Cummings-John, a member of the anti-colonial West African Youth League (WAYL), and leader of the Women's Movement, the first women's group to campaign for women's inclusion in politics and public life, actively participated in the national strike of 1955. Although the activities of the organisation declined after the Sierra Leone People's Party (SLPP), the party of independence, lost the 1967 general election and Mrs CummingsJohn was subsequently exiled to England, it has been observed that the association's 'role in mobilising women at the grassroots level for economic reasons was a significant development that inspired subsequent women's associations and promoted a high level of political consciousness among women' (Steady 2006: 64).

These promising beginnings for women's political participation at the birth of the new independent nation of Sierra Leone were to falter with the imposition of a one-party state by the All People's Congress Party (APG) in 1978 and, with it, an end to women's embryonic independent political activism and mobilisation. As a result, women's voices and their participation in the public-political arena became extremely marginal. Women in the public domain either had to kowtow to the state's political line or become apolitical, thereby limiting their ability to organise and challenge existing discriminatory policies and practices in society. When women became 'political', they were mainly cheerleaders and foot soldiers of the APC.

\subsection{Women's voice in the conflict era}

With the onset of the civil war in 1991, and the military coup of 1992, women's activism turned to efforts to bring about peace, and a transition to democratic governance. Women's token representation continued during the Strasser military regime of 1991-6, with only one female member of cabinet. But outside the formal political arena women became actively engaged in the peace process in 1994, as part of the preparatory effort towards the Fourth World Conference on Women (the Beijing conference), held in 1995.

Despite their marginalisation from the public decision-making process, Sierra Leonean women like their counterparts in Burundi, the Democratic Republic of Congo, Liberia, Somalia and Rwanda became the torchbearers of peace. In 1994, the Sierra Leone Association of University Women (SLAUW) proposed the creation of a network for women to meet regularly and share information on issues of common concern. This initiative led to the creation of the Sierra Leone Women's Forum as the umbrella organisation of over 50 women's groups. Although the Forum's objective was networking for the Beijing conference, due to the devastating effects of the civil war on the economy and society and especially on women, they decided to organise in support of the peace process.

The Sierra Leonean Women's Movement for Peace (SLWMP) and Women Organised for a Morally Enlightened Nation (WOMEN), two Forum members, spearheaded women's political organising for peace and democratisation. They organised demonstrations, campaigns, peace matches, debates and prayer rallies and mobilised and built cross-class alliance among women. Women's influence was felt in both National Consultative Conferences in 1995 and 1996. To ensure that conference delegates and the general public maintained their stance on the democratisation project, the Women's Forum embarked on sensitisation campaigns: organising public rallies and press conferences, issuing communiqués and organising meetings to reinforce public opinion in support of the transition programme. In one of their communiqués, the women demanded to be 50 per cent of any peace delegation and demanded involvement in decision-making at all levels. Yet there was no female participant at the Abidjan Peace Accord meeting. In the subsequent elections, women's political representation remained low: women won only five out the 80 contested parliamentary seats, two women were appointed ministers out of a cabinet of 25, and two were assigned deputy ministerial positions out of 20 deputy ministers. 
The Abidjan Peace Accord notwithstanding, the civil crisis continued and on 25 May 1997, the Armed Forces Ruling Council in alliance with the Revolutionary United Forces (RUF), the rebel grouping overthrew the elected government. Once again, women took an active part in the pro-democracy campaigns. However, they could not organise as a group due to the repression and brutality of the coupists. Consequently, they engaged in covert activities as undercover agents infiltrating the junta, exposing their activities in arms deals, diamond smuggling and naming its international partners (Solomon 2005a).

\subsection{Marginalised again: the post-conflict era}

The war was officially declared over in January 2002 and the first post-conflict election took place in May 2002. Despite their pro-democracy and peace activism during the conflict phase, women were once again marginalised in the formal peace process and in post-conflict public political space. When the Government of Sierra Leone and the RUF rebels signed the Lomé Peace Accord in July 1999, there were only two female members of the delegation - one from each side of the conflict. Furthermore, the Accord had only one reference to women within the body of the text:

Given that women have been particularly victimised during the war, special attention shall be accorded to their needs and potentials in formulating and implementing national rehabilitation, reconstruction and development programmes, to enable them [to] play a central role in the moral, social and physical reconstruction of Sierra Leone. (cited in Eno 2000: 74)

From the above, it can be argued that Sierra Leonean women's activism was not given due recognition either by the state or the international community as they were not recognised as actors and agents of change and peace. Rather, they were seen as victims who should be protected and taken care of.

Women's activism continued as different women's groups mobilised to get more women and women's issues on to the political agenda. The most prominent organisation in this phase of women's political activism was the 50/50 group. Founded in 2001, with the objective of having equal representation of women and men at every level of decision-making structures, the group's activities included recruiting, training and supporting women seeking elected office in order to remove obstacles hindering their political participation. The 50/50 group's frontal engagement with the patriarchal political system resulted in an increase in women's political representation in the 2002 general election and in elective and political appointments. There was one female presidential candidate and two women presidential running mates. Overall women represented 14.5 per cent of parliamentarians, representing over 100 per cent increase from the 1997 figure of 7.1 per cent. Women constituted 19.3 per cent of ministerial and deputy ministerial appointees. This figure is also more than a 100 per cent increase from 8.8 per cent in 1997. In the 2004 local government elections, 11.8 per cent of elected local government councillors and 5.2 and 10.5 per cent of local government chairs and deputy chairs respectively were women. Sixteen women were elected to parliament in 2007 and in the 2008 local government elections, the number of female councillors increased from 13 per cent to 18.9 per cent. While there is no female chair of a local council, the number of deputies increased from 10.5 to 15.7 per cent. And the new phenomenon of female independent candidates also emerged in Sierra Leone's political landscape. Of the 1,380 contestants for councillorship in the 2008-13 local election cycle, 13.9 per cent were female independent candidates. ${ }^{\prime}$

Women's intervention in the public-political space during the crisis changed the nature, course and discourse on the peace process and Sierra Leonean politics in general. Why then were Sierra Leonean women unable to maintain the momentum and utilise the opportunities created by the conflict to make their mark in post-conflict politics and reconstruction policies? Various explanations have been put forward. For Jusu-Sheriff (2000), a Forum activist, the women's movement was unable to seize the new opportunities created by the conflict because it lacked a clear and strong ideological framework and strategy to confront entrenched patriarchal structures in the society. For Dyfan, another Forum activist, the women's focus was more on ensuring that the democratisation process was not derailed and that the election process was free and fair than on increasing women's participation in politics as leaders and decisionmakers (quoted in Steady 2006: 46). Steady's analysis of the process points to other issues: 
... the Women's Forum did have an ideological framework in their commitment to democratisation, peace, development and the advancement of women. What they lacked was a strategic plan of action to implement their vision and ideological position. Problems of resource constraints also contributed to derailing prompt and effective action toward a realistic and meaningful process of democratisation. (2006: 58)

In addition to the views outlined above on the failure of the Sierra Leonean women's movement to transform the country's political landscape, we believe that the historical antecedent of the movement affected its engagement with the political process and its outcomes. The failure to develop women's independent political voice after Mrs CummingsJohn's exile, the APC's authoritarian rule and the creation of the Women's Congress as the legitimate political voice of women affected the movement's participation and response to the new political openings. Given the above, can we say that Sierra Leonean women are empowered? It can be argued that despite the Forum's massive political mobilisation and sensitisation campaign during the war years, Sierra Leonean women are still not politically empowered. However, there is a groundswell of political activism taking place among elected women officials at the national and local levels and among civil society organisations aimed at sensitising the populace on the need for more elected female officials. For example, elected female politicians and local councillors have established cross-party organisations to promote women and women's issues in parliament and local government structures. ${ }^{2}$ Within civil society, a coalition of women's groups created the Women's Solidarity Fund ${ }^{3}$ in 2008 to support female local council contestants. The Fund focused primarily on funding and promoting female independent candidates.

\section{Work and access to resources}

Even though their contributions have often been undervalued and taken for granted, Sierra Leonean women have always been an integral part of the country's workforce and economic development. There have been an impressive number of women in influential positions ranging from paramount chiefs, political activists, high court judges, educators, entrepreneurs, businesswomen and cabinet ministers to presidential candidates. Women are also well represented in the civil service, the legal profession, police force, military, teaching and nursing and some have held top notch positions such as permanent secretaries, director-generals, chief medical officers and top ranking officers in the army.

However, the presence of women in the public sphere and positions of authority has not necessarily closed the gender gap. Even though many Sierra Leonean women have transgressed and continue to transgress masculine/public spaces in terms of work and access to resources, they are still the minority and, in some instances, are operating from a framework designed by male leaders/politicians who act as their patrons. The majority of Sierra Leonean women are uneducated, lack or have limited access to capital, education, land, etc. and live under

discriminatory customary laws that assign them second-class citizenship. While the civil war made women's lives more difficult in many ways, it also created spaces for women to agitate for change in relation to their access to resources - whether education, jobs or other economic opportunities.

\subsection{Women in the labour force}

As is the case the world over, most women in Sierra Leone work double shifts in the formal or 'informal' economy and as home managers, taking care of the daily business of running a family. Unfortunately, their productive and reproductive labour in the domestic sphere never figures in the economic index. According to the Sierra Leone Human Development Report (UNDP 2007), there were more women (13 per cent) in the labour force than men, but they worked mainly in the informal sector, in activities such as gara making (tie-dyeing), soap making, basket making, oil extraction, hairdressing, childcare and petty trading, none of which yield high incomes.

Women in Sierra Leone have a long history of engaging in trade whether at the local or subregional level probably because trade has always been the one activity that provides them with immediate employment/subsistence. Some of these traders own shops in which they sell foodstuffs or imported clothing and others sell in the marketplaces or from their homes to friends and relatives. Because most of these women engage in petty trading and do not own big 
business ventures, they have always found it difficult to secure credit from financial institutions, whose demands they often cannot meet. The two main ways that they had traditionally been able to access capital, through cooperatives and osusu (rotating credit) clubs, have been and continue to be the most popular forum for mobilising capital. Postwar unemployment and postwar reconstruction strategies such as the availability of microcredit have led to an upsurge in petty trading. Unfortunately, many of these women barely break even and whatever profit they make goes toward feeding and taking care of the immediate needs of their households which often does not include comprehensive healthcare and meeting most of the educational needs of their children. It can be argued that these economic hardships have led to many anti-social behaviours such as enlistment in the rebel movement and engaging in sugar-daddyism, that is, taking older male lovers for economic support.

\subsection{Economic opportunities during and after the conflict}

During the war, rebel camps became an opportunity and alternative to a better life for many young women. As Binta Mansaray explains: 'Looting was also a reason why some women stayed in the movement: in a society that had so deprived them, they knew that they would never get the opportunity to legally earn a fraction of their gain from raiding and looting villages' (2000: 146). In effect, war zones become 'a space in which social and economic opportunities unavailable in "safe" areas (such as refugee camps) could be found' (Utas 2005: 421). Solomon (2005b) documents the benefits and risks involved in trading in rebel zones during conflict. As the effects of the UN-imposed sanction of 8 October 1997, banning the sale of arms, petroleum and petroleum products impacted on the society, a thriving black market sector emerged that was extremely profitable to female traders. According to her narrative, in spite of the risks such as road accidents sometimes resulting in deaths, ambush and dispossession, market women ventured into the rebel zone to sell the goods they had smuggled across the border from Guinea.

... they were paid either in cash (Leones or Dollars) or in kind, including jewellery, gold or diamonds. Back in Freetown, market women either sold their diamonds to Lebanese dealers or smuggled the gems across the border to Guinea where they fetched higher prices enabling them to buy more food stuffs... Some died in gruesome road accidents on their way to the provinces never making it to their destinations. Others were ambushed on their way back to Freetown by the same rebels they had earlier traded with. Sometimes their 'customers' would send their 'boys' after they had concluded their transactions, to retrieve the money and/or valuables the women had earlier received as payments (Solomon 2005a: 10).

After the war, there was a large increase in sex work fuelled mainly by the presence of a large contingent of UN and ECOMOG (Economic Community of West African States Monitoring Group) peacekeepers and the large numbers of internally displaced people and orphans in the country. Many of these sex workers head households and take care of extended family members with their earnings. Even though many female ex-combatants are said to be engaged in sex work, the majority have been trained as hairdressers and seamstresses as part of the Disarmament, Demobilisation, Reintegration (DDR) programme. The aim of the rehabilitation part of the programme was to make them selfemployed. However, even as these trainings help to create employment, they also hinder women's advancement in the formal sector. With limited skills and no formal education, it will be impossible for these women to occupy upper and middle-management positions, have equal access or close the gender gap.

Women's access to productive resources remains precarious, despite high levels of female participation in agricultural activities. Even in areas such as farming, where women continue to outnumber men, they have limited or no access to land. Moreover, when they do have access to land they are denied credit by financial institutions because of reasons that are often gendered. According to the country's National Policy on the Advancement of Women, '60-80 per cent of women earn their living through agricultural activities and are engaged in 90 per cent of food production' but yet 'they have less access to technical and financial inputs than their male counterparts' (Government of Sierra Leone 1998: 7).

Now more than ever, many Sierra Leonean women are developing different survival 
strategies and reconstruction plans to help them deal with the harsh realities of a postwar society. Microcredit revolving loan schemes, the main programme in the government's, development agencies' and local non-governmental organisations' (NGOs') economic reconstruction project, is seen as the vehicle to help women rebuild their lives, create a source of livelihood, and gain financial independence and ultimately economic empowerment. Using the effects of microcredit on the lives of market women in Sierra Leone, Solomon argues that not only did microcredit create employment opportunities for women, increased self-sufficiency and improved the standard of living in postwar Sierra Leone, but also increased women's political participation in local organisations and awakened their sense of involvement in the economic reconstruction of the society (Solomon 2005a: 13). She notes further that while these were important changes, it did not alter existing gender relations in the society.

\section{Bodily integrity}

In pre-war Sierra Leone, issues such as rape, sexual violence and domestic violence were hardly discussed or addressed. Though now curtailed, practices such as early and forced marriages whereby very young girls are given in marriage to men old enough to be their grandfathers still persist, remain acceptable and are hardly challenged. As a result, immature girls face early sexual activity and are exposed to risks and complications arising out of early pregnancy and childbirth. The situation of women is further worsened by an inadequate, unaffordable and inaccessible healthcare system in the country, making Sierra Leone a country with one of the highest maternal and infant mortality rates. ${ }^{4}$

\subsection{Sexual violence in the pre-conflict period}

Discussing and reporting rape and other forms of sexual violence against women and girls has always been an uphill task. In pre-war Sierra Leone, women and girls had much more difficulty reporting rape and other sexual violence they experienced because, for one, they were made to believe that they were responsible for the acts perpetrated against them. Perpetrators were hardly prosecuted or made accountable for sexual crimes committed against women and a culture of silence and impunity pervaded the society. In many cases, the discovery of sexual violence committed against a girl or a woman was usually addressed not by the victim, but by family members who felt that the family honour had been violated. Moreover, the virginal status of the girl or woman greatly influenced the reaction of the family. Where the sexual abuse of a virgin girl or woman was discovered, the family or community had various means of dealing with the situation. Often the focus was on reclaiming the dignity of the family. In the rural areas, most sexual violations were addressed without recourse to the courts, but dealt with by chiefs, community elders and religious leaders. Among most ethnic groups the perpetrators are required to pay an amount as a fine and in cases where the woman is married such fines are known as woman damage. In a few ethnic groups, physical punishment may be inflicted on the perpetrator and in other ethnic groups the perpetrator may be forced to marry the victim leading to a further violation of the rights of the victim.

The phrase 'domestic violence' was rarely used before the conflict, and violence within the home or in a relationship was never considered to be domestic violence. Such behaviour was considered almost normative and among certain ethnic groups physical chastisement of wives was a right husbands had and were free to exercise. The culture of silence, in relation to domestic violence, was so prevalent that even educated women who were victims of domestic violence rarely reported such crimes. Even though acts of domestic violence could be prosecuted within the legal framework under the crime of assault, wounding, manslaughter or murder, in both rural and urban areas, sexual violence cases, including rape, were hardly ever taken to court. Police were often reluctant to investigate because they believe that they were personal, belonged to the domestic realm and ought to be addressed at home or within the family structure. The victim's fear of ostracism, stigma and shame often prevented them from testifying in public. Archaic laws and the gender insensitivity and unreasonable bureaucratic delays of the justice system were a further obstacle. Impunities escalated and became manifest during the war.

\subsection{Violations in a time of war}

The violations that women and girls experienced during the war were characterised by the most extraordinary inexplicable acts of violence, leaving many women permanently scarred. The 
Truth and Reconciliation Commission (TRG) report notes that 'women and girls were the deliberate targets of sexual violence and rape by all the armed groups during the conflict' (Government of Sierra Leone 2004: 167, 169). Women and girls were tortured as various objects such as firewood, sticks, and guns were inserted into their private parts. Some women were forced to have sex with other male members of their families such as their sons and wards. There were also a few reports of disembowelment of pregnant women and torture and killing of babies in their mother's presence. Some women and girls had their arms and limbs amputated. Abducted women and girls experienced sexual slavery and forced marriage. An estimated 58 per cent of women suffering sexual violence were repeatedly violated by multiple perpetrators. Furthermore, to instil fear and deter abductees from escaping, the different warring factions often tattooed or marked their victims with knives, blades and other sharp instruments on various parts of their bodies. The abuse of women was indeed a weapon of war and a strategy designed to destroy the norms and values of the society.

The violations committed against women and girls continue to have a negative impact on their lives in postwar Sierra Leone. Because of societal sanctions against abortions and lack of access to proper healthcare, a lot of women had to carry unwanted pregnancies and have become single mothers in a postwar society in which life can be unbearably difficult. Psychosocially, many women suffer in silence, carry the shame and stigma of their rape and abduction experience and are reluctant to discuss these experiences or seek help. Some women suffer permanent or irreparable injury as there has been an increase in sexually transmitted diseases including HIV/AIDS. In effect, widowhood, ostracism and forced pregnancies have led to an increase in female-headed households where families live in very poor conditions. However, postwar reconstruction efforts, through the creation of gender-sensitive programmes, have begun to address many of these problems.

Although the terms of reference of the TRC made no reference to women, in undertaking its task, the TRC invited and received submissions from NGOs, women's groups and other activists on the issue of violence against women during the war. It also invited and recorded testimonies from victims of sexual and other abuses. It particularly dealt with the status of women before the conflict in order to ascertain links with such abuses of women before, during and after the conflict. The TRC was gender sensitive and in its processes ensured that gender issues were taken into account. Reports of the violence women faced during the conflict led to the proliferation of agencies and NGOs operating in Sierra Leone. The efforts and successes of these organisations are debatable because there are a large number of victims who claim that they have not benefited from such programmes. During the special hearings for women at the TRC most victims of sexual violence complained that they had not received any medical assistance and that they continue to experience health problems related to the sexual abuse they encountered during the war.

\subsection{Current challenges}

Violence against women continues to prevail in the society as a result of the structural inequalities women face, absence of law reform to address such violations and the continued application of discriminatory laws. One important change as a result of the war is the increased and sustained activism of women advocating for peace democracy and good governance. In their campaigns, women have also skilfully advocated for the respect and protection of women's rights, the prosecution of offenders and law reform to restore the dignity of women. We now have a lot of women's groups advocating for women's rights at all levels and the momentum is building.

The Ministry of Social Welfare, Gender and Children's Affairs has been involved in a lot of initiatives towards the protection and promotion of the rights of women. Other manifestations of an increased political will to address women's rights issues are the setting up of the Family Support Unit by the Sierra Leone Police Force to address sexual violence and domestic violence. There has also been a marked increase in the reporting, investigation and prosecution of sexual and domestic violence. The media regularly reports incidences of sexual violence, particularly against minors, and domestic violence even though reports about prosecution or conviction of these offences are almost non-existent.

Even though the need to address sexual and domestic violence is part of the wider postwar 
discourse on women's empowerment, there are challenges towards the elimination of such violence. For one, the policies developed by the Ministry of Social Welfare, Gender and Children's Affairs on the Advancement of Women and Gender Mainstreaming are hardly implemented. These policies recognise the historical discrimination against women and the need to ensure that the rights of women are secured and promoted in all spheres of society. The establishment of the Family Support Unit of the police is recognition of the need for the enforcement of the laws against sexual and domestic violence, but their work is hampered by lack of personnel, training and other support.

Through the collaborative efforts of the Parliamentary Human Rights Committee, the United Nations Development Programme (UNDP) and civil society groups, laws that were drafted to cover domestic violence, minimum age of marriage (18 years), customary marriage laws, divorce registration and inheritance laws, and marriage rights in general were adopted by Parliament in June 2007. These Bills ${ }^{5}$ commonly known as the 'Gender Bills' seek to implement the provisions of the Convention on the Elimination of All Forms of Discrimination against Women (CEDAW) that advocates for the removal of discriminatory laws and to ensure that the rights of women are secured and enforced. These Bills are the outcome of nationwide consultation. With a comprehensive legal framework in place, women will begin to address the structural inequality, discrimination and abuse they face on an everyday basis.

\section{Conclusions}

The Sierra Leonean women's movement, as an organised force, was able to confront the

\section{Notes}

1 Women stood as independent candidates after they were sidelined in the nomination process by their parties.

2 Network of female parliamentarians and ministers revived in 2008 and network of female councillors established in 2009. challenges brought on by the civil war, by increasing their voices and participation in the political space, and their bargaining power in the household as well as changing the discourse on bodily integrity during the conflict phase. However, it was not able to fully use the opportunities created by the war to advance a women's agenda for gender equality and empowerment in the immediate post-conflict reconstruction process. This is in spite of the fact that postwar Sierra Leone has seen an increase in the number of local and international NGOs headed by women and with a focus on empowering women. As they advocate for voice, participation, bodily integrity and help to provide access to work, education, land, the legal system, healthcare, credit, etc., these women and their organisations have not only been instrumental in changing the lives of many women but also in creating the space for other Sierra Leonean women to advocate for change.

The war and its effects on the society resulted not only in the emergence of a pathway for women's empowerment, but the adoption of the Gender Bills, the submission of Sierra Leone's country reports to the GEDAW committee and the establishment of the family support unit within the police force, and serve as pointers towards Sierra Leonean women's journey of empowerment. Furthermore, the establishment and the effective functioning of the Human Rights Commission, it is hoped, will create more awareness on women's rights and help to protect and advance those rights and address issues of sexual and domestic violence. Even though nationwide sensitisation and awareness-raising campaigns about the rights of women remain a great challenge, work towards the restoration of the dignity and integrity of women is in full force.

3 Campaign for Good Governance, 50/50, Search for Common Ground and Gender Empowerment Movement.

41,800 per 10,000 live births.

5 Domestic Violence Act, Customary Marriage Act and the Succession Act. 


\section{References}

Eno, J. (2000) 'Women's Strategies for Peace: Gains and Losses in Sierra Leone', Workshop Report on Conflict Transformation in Africa: African Women's Perspectives, Dakar, 23-26 May, London: International Alert and AAWORD, www.InternationalAlert.org/ publications/82.php (accessed 27 June 2006)

Government of Sierra Leone (2004) Truth and Reconciliation Commission Report, Freetown: Government of Sierra Leone

Government of Sierra Leone (1998) Sierra Leone National Policy on the Advancement of Women, Freetown: Ministry of Social Welfare, Gender and Children's Affairs

Jusu-Sheriff, Y. (2000) Sierra Leonean Women and the Peace Process, London: Accord, www.c-r.org/ accord/s-leone/accord9/ women.shtml (accessed 28 June 2006)

Mansaray, B. (2000) 'Women Against Weapons: A Leading Role for Women in Disarmament', in A. Ayissi and R-E. Poulton (eds), Bound to Cooperate: Conflict, Peace, and People in Sierra Leone, Geneva: United Nations Institute of Disarmament Research
Solomon, C. (2005a) 'The Mano River Union Sub-region: The Role of Women in Building Peace', in E. Onubogu, L. Etchart, R. Baksh and T. Johnson (eds), Gender Mainstreaming in Conflict Transformation: Building Sustainable Peace, London: Commonwealth Secretariat

Solomon,C. (2005b) 'The Role of Women in Economic Transformation: Market Women in Sierra Leone', paper presented at the Transformation of War Economies-Expert's Conference, Plymouth, 16-19 June

Steady, F. (2006) Women and Collective Action in Africa, New York: Palgrave Macmillan

Turshen, M. (1998) 'Women's War Stories', in M. Turshen and C. Twagiramariya (eds), What Women do in Wartime; Gender and Conflict in Africa, London: Zed Books

UNDP (2007) Sierra Leone Human Development Report, Freetown: United Nations Development Programme

Utas, M. (2005) 'Victimcy, Girlfriending, Soldiering: Tactic Agency in a Young Woman's Social Navigation of the Liberian War Zone', Anthropology Quarterly 78.2: 403-30 